\title{
Socio-economic impact of system of rice intensification (SRI) and traditional rice cultivation in Villupuram district of Tamil Nadu : experiences from TN-IAMWARM Project
}

\author{
V.K. RAVICHANDRAN* AND K.C. PRAKASH ${ }^{1}$ \\ Department of Agronomy, TN-IAMWARM Project, Tamil Nadu Agricultural University, COIMBATORE (T.N.) INDIA \\ (Email : vkr9999@yahoo.com,k.c.prakash26@gmail.com)
}

\begin{abstract}
The study has assessed the socio-economic impact of rice intensification. The results of the study revealed that, variables namely age, education, farming experience, SRI experience, information seeking behaviour, training attended, extension orientation, economic motivation, risk orientation, market perception, innovativeness and attitude were found to be positively significant at 1 per cent level of probability with their extent of adoption of SRI technology. The most important constraint in SRI cultivation has been identified as usage of cono-weeder $(58.21 \%)$ followed by nursery management $(56.61 \%)$. The adoption of SRI technique has helped increase the rice production without increasing the area under its cultivation and has proved to serve as an alternative method for rice cultivation.
\end{abstract}

Key Words : Socio-economics, Attitude, Adoption, SRI technology

View Point Article : Ravichandran, V.K. and Prakash, K.C. (2015). Socio-economic impact of system of rice intensification (SRI) and traditional rice cultivation in Villupuram district of Tamil Nadu : experiences from TN-IAMWARM Project. Internat. J. agric. Sci., 11 (1): 166-171.

Article History : Received : 13.11.2014; Revised : 03.12.2014; Accepted : 17.12.2014

\footnotetext{
* Author for correspondence

${ }^{1}$ TN-IAMWARM Project, Tamil Nadu Agricultural University, COIMBATORE (T.N.) INDIA
} 